\title{
What are the prerequisites for a euro-area fiscal capacity?
}

\author{
Maria Demertzis and Guntram B. Wolff
}

\section{Executive Summary}

MARIA DEMERTZIS (maria. demertzis@bruegel.org) is a Research Fellow at Bruegel. Guntram B. WoLFF (guntram.wolff@ bruegel.org) is the Director of Bruegel.

This is the background paper for the presentation given at the informal ECOFIN in Bratislava on 9 September 2016. A shortened version of this paper was circulated to the Ministers and is also available for download on the Bruegel website.
A MONETARY UNION without fiscal union is generally considered to be incomplete. We consider three steps for increasing the centralisation of fiscal functions, and discuss the prerequisites for moving forward at each one. Above all, fiscal integration is a matter of trust, which is currently at a low level.

THE FIRST STEP would be to complete banking union and establish a more credible no-bailout clause. The conditions for addressing the fiscal dimensions of banking union are a denationalisation of the banking policy framework - including as regards exposure to sovereign debt - addressing non-performing loans and legitimising the fiscal backstop.

THE SECOND STEP would move on from the first by adding funds for public goods and investment in the EU. This step would create a re-insurance framework to help euro-area countries absorb large shocks. We consider a review of the EU budget and additional resources as conditions for this scenario. A system of check and balances is important. Last, we consider structural convergence to better deal with shocks as an essential prerequisite for mechanisms to cope with large shocks.

THE LAST STEP constitutes our analytical benchmark as it would move substantial government spending to the central level. This would allow euro-area fiscal stabilisation to be fully centralised. To enable this scenario, real economic differences between countries need to be lower, and a proper political union would need to be established, with legitimacy and a level of political integration very different from the situation today.

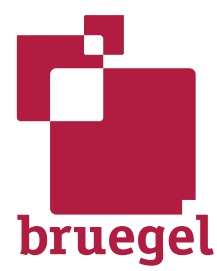




\section{Introduction}

The debate on what kind of fiscal union is needed for Europe's monetary union dates back to before the start of Economic and Monetary Union (EMU) (Eichengreen and von Hagen, 1996) and re-emerged with the more recent crisis ${ }^{1}$. One view is that fiscal union for the euro area was rejected before monetary union started because it would have required political union, which member states did not want. But the view held by others, perhaps most notably former German chancellor Helmut Kohl, was that the euro would ultimately lead to irreversible European unification (Mody, 2014).

Historical-comparative research typically finds that monetary and fiscal unions go hand in hand. Functioning federations require at a minimum a credible no-bailout clause for sub-federal debt and a central budget that provides federation-wide public goods and services. The central budget is decided on by way of appropriate mechanisms that ensure political legitimacy. In established political unions, this central budget is typically large enough to provide fiscal stabilisation (Bordo et al, 2011).

The United States of the founding fathers often serves a yardstick of comparison for the EU. But such comparisons have limitations ${ }^{2}$. The level of political integration that already existed in the US, the relatively small debt markets and the unsophisticated nature of the financial system at the time mean that such comparisons are not entirely relevant to the euro area. Furthermore, since US states had an overall small government sector, it was a comparatively small step to add the federal layer. But in the euro area, government spending is much larger, at between 40 percent and 58 percent of GDP. If fiscal union is to be understood as a centralisation of fiscal policy, one would have to discuss the shifting of significant spending from the national to the union-wide level.

Discussing fiscal union is not easy in current circumstances. Trust in the European Union has fallen in recent years and remains at low levels (Figure 1). But some survey evidence suggests that support for the EU has risen in a number of countries after the Brexit vote ${ }^{3}$. Nevertheless, the United Kingdom's vote to leave the EU is often interpreted as a pushback against far-reaching integration steps ${ }^{4}$, though there is a counter view that the only way to salvage the monetary union project is to undertake further integration steps to improve its performance ${ }^{5}$. But there is substantial intellectual disagreement on what further integration steps would actually be helpful and necessary ${ }^{6}$.

In our assessment, the current euro-area institutional set-up has a number of key problems. The current fiscal rules are not implemented ${ }^{7}$, they lack credibility and do not achieve the optimal combination of fiscal sustainability and fiscal stabilisation. The EU's fiscal framework has also been shown to suffer from significant measurement problems (Claeys and Darvas, 2015). A further problem is the absence of the definition of a fiscal policy stance for the euro area as a whole in a situation in which the effectiveness of monetary policy is constrained by the zero lower bound (Benassy-Quéré et al, 2016). Trust is missing that necessary fiscal buffers are available to enable national automatic stabilisers to play their role in case of a shock. Risk-sharing between countries to cater for large national shocks is limited. Never-

1 See for example Marzinotto, Sapir and Wolff (2011); PIsani-Ferry, Vihriälä and Wolff (2013); von Hagen (2014); Benassy-Quéré, Ragot and Wolff (2016); Macron and Gabriel (2015); van Rompuy (2012); Eichengreen and Wyplosz (2016); Mody (2015).

2 Frieden (2016) and Henning and Kessler (2012) provide overviews.

3 According to surveys from YouGov, support for remaining in the EU increased relative to leave in Germany, Finland, France and Sweden, while it decreased in Denmark, between end-May and end-July 2016.

4 See Tusk (2016); Schäuble (2016).

5 See Gabriel and Schulz (2016); Verhofstadt (2016).

6 Baldwin and Giavazzi (2016) formulate an economists' 'consensus' narrative. This however, is not uniformly shared, showing the disagreement in academic circles.

7 Darvas and Leandro (2015) show that implementation even lacks behind the implementation of recommendations by international institutions such as the OECD. 
theless, there is a perception that the no-bailout clause is not credible and financial assistance might even be given to countries with unsustainable debt.

\section{Figure 1: Trust in the EU}

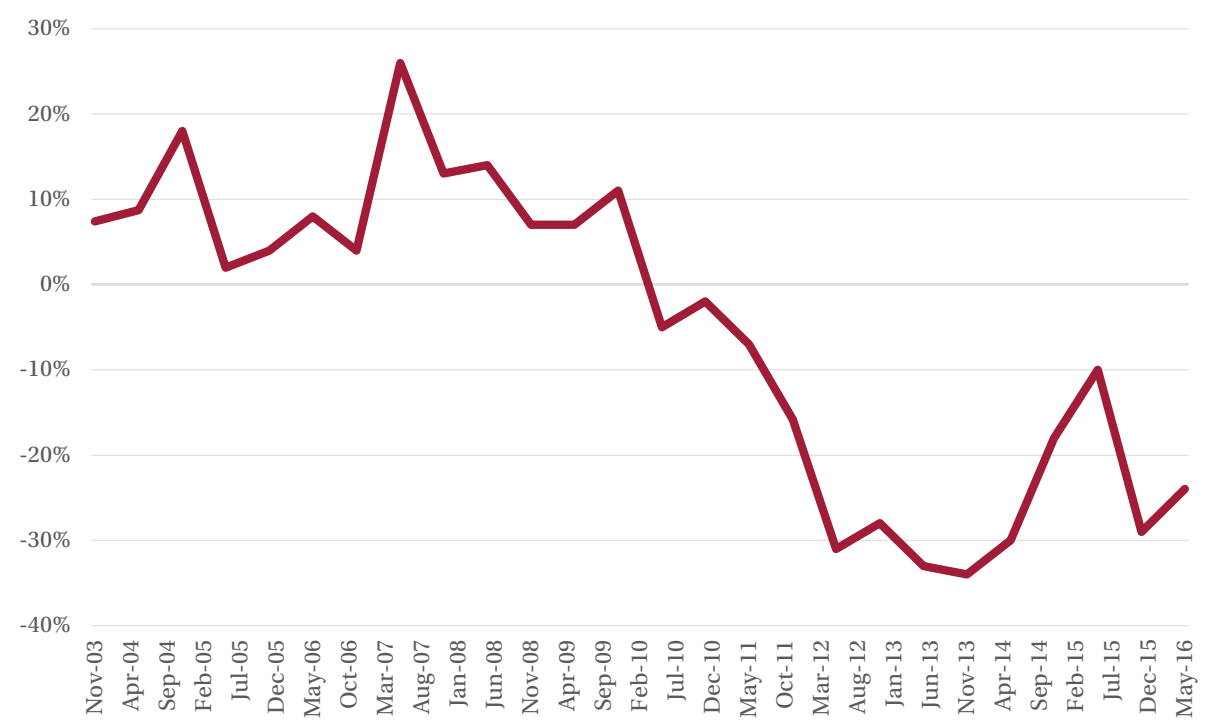

Source: Bruegel based on Eurobarometer. Note: Trust is measured as net trust in euro-area countries. Net trust is computed as the difference between 'tend to trust' and 'tend not to trust'.

It is against this background that we discuss three progressive steps for strengthening the fiscal framework at the euro-area level ${ }^{8}$. These lead to less interference in national fiscal policymaking thanks to a more credible no-bailout clause, increased risk sharing and different degrees of provision of euro-area-wide public goods and fiscal stabilisation ${ }^{9}$.

\section{Strengthening the euro area's fiscal framework in three steps}

We consider increasing fiscal centralisation in three consecutive steps ${ }^{10}$. This first step can be seen as the minimum required to put the euro area onto a more stable footing, while the third can be seen as an analytical benchmark with a centralised fiscal budget and sufficient resources to fulfil a stabilisation role. The second step is an intermediate one that would help strengthen efficiency by centralising a small number of activities, establishing better provisioning of European public goods and introducing elements of risk sharing for large idiosyncratic shocks.

Responsibility for decision-making over fiscal policy has been and remains largely national, despite an elaborate EU framework of fiscal rules. An effective fiscal framework should assign responsibilities and legitimacy clearly between the European and the national levels. This means that in extreme situations, the no-bailout clause needs to have some credibility. We define the no-bailout clause in line with Article 125 of the Treaty on the Functioning

8 The three steps are comparable but not identical to those outlined in the Five Presidents' Report: $\underline{\text { https://ec.europa.eu/priori- }}$ ties/sites/beta-political/files/5-presidents-report en.pdf.

9 The table in the annex summarises our three steps and lists the conditions that are needed in each case.

10 This is one of the parallels with the proposals in the Five Presidents' Report. 
of the EU: it allows the possibility of providing a loan on the condition that debt is sustainable, but it does not allow the assumption of unsustainable debt. We define credibility as the existence of a hard budget constraint, ie a financial assistance programme will only be approved if the country passes the debt sustainability analysis ${ }^{11}$. The no-bailout clause is more credible with greater financial stability. A fiscal backstop for the financial system and for essential government spending (for example through a European Stability Mechanism/Outright Monetary Transactions (ESM/OMT) programme) can achieve greater stability. More specifically, to enhance financial stability, it is important to reduce the exposure of banks to sovereign decisions and sovereign debt ${ }^{12}$.

The credibility of the no-bailout clause depends, somewhat paradoxically, on the level of fiscal and financial centralisation. When important government functions are centralised, it becomes easier to maintain stability in extreme situations, compared to unions in which the sub-central level carries out almost all functions of government. The degree of fiscal and financial centralisation and the enforcement of responsibilities at the national level are therefore linked.

\subsection{Step A: completing banking union}

Our step A would complete first and foremost the banking union. This still requires a European Deposit Insurance System, an appropriate fiscal backstop and a further denationalisation of banking policies, including less exposure to sovereign debt and changed bank ownership structures. Banking union is indispensable in a monetary union that wishes to ensure stability, even in the face of possible sovereign debt crises. Financial stability crucially hinges on the stability of banks. Finally, and with all of the above achieved, we would subsequently envisage a gradual reduction in the intrusiveness of European fiscal rules and a reform of the EU's fiscal rules.

It is important that the ESM and OMT programme continue to exist in order to ensure that sovereign debt is not subject to self-fulfilling liquidity crises. Sovereign debt would remain a national responsibility and a safe asset comparable to sovereign debt outside of monetary unions. Only, in extreme cases, if the Eurogroup/ESM decides that debt is not sustainable, would its nature change.

This scenario would not address the problem of the macroeconomic management of the euro area as a whole. In particular, when interest rates are at the zero lower bound, the European Central Bank becomes less effective in achieving its inflation target. In such situations, it would be up to fiscal and economic authorities to support macroeconomic management with appropriate fiscal and structural policies. But in this first step, there would be no central tool other than monetary policy to ensure price stability. Loose fiscal policy coordination should play a role but is unlikely to be fully up to the task.

A second problem would be that for countries that mismanage their public finances and lose market access, there would be limited fiscal instruments other than the ESM to prevent large, pro-cyclical fiscal tightening.

A third unaddressed problem is the absence of any financing mechanisms to provide for commonly shared public goods, such as climate policies or security and defence measures.

\subsection{Step B: Providing European public goods, financing investments and insuring against large idiosyncratic risks \\ In our second step, we envisage adding a small fiscal capacity, which would fund} some European public goods, such as external and internal security, climate policies and migration policies, beyond what is currently funded by the EU budget. The fiscal capacity

11 This condition is central to the European Stability Mechanism treaty. In practice, it is well known that debt sustainability analysis is not clear-cut. Ultimately, markets will judge the credibility of the no-bail-out clause by not instigating a credit event. 12 Pisani-Ferry (2016). It is an open question whether the euro area needs a formal debt restructuring mechanism, with plausible arguments for and against. 
would also provide resources for pan-European investment. This part of fiscal union need not be restricted to the euro area, but can involve the EU as a whole, because the public goods are not just for the euro area. Moreover, an insurance system (for example European unemployment reinsurance) would be established to help euro-area countries that are hit by large shocks.

The important value added of this second step is that it would provide common solutions to problems shared by European citizens - so truly European public goods. In addition, depending on the way these goods are funded, the fiscal capacity could contribute to cyclical stabilisation of the euro area as a whole. The more cyclical the revenue sources, the greater their stabilisation properties could be. Such fiscal capacity could create a social mechanism to mitigate the impact of major recessions on those most affected. The implied risk sharing would also somewhat help with national fiscal stabilisation policies, should national borrowing become constrained ${ }^{13}$.

But overall it is clear that this scenario does not create a fiscal capacity at the euro-area level to manage fiscal stabilisation policies. Maintaining sound national fiscal policies would remain crucial to allow the necessary fiscal space so that automatic stabilisers can play their roles in full.

\subsection{Step C: A true fiscal federation with spending and taxing powers at the federal level}

Our last step C, which we consider an analytical benchmark, would shift significant spending items to the federal level in order to centralise or federalise important functions of fiscal and public policy. This would be a much more ambitious plan that aims to apply European solutions in areas such as defence and social policy. The federal level would take care of significant parts of stabilisation policy, for example through centralised unemployment insurance, health insurance and pension system amounting to perhaps 20 percent of total government spending. It would make the euro area's fiscal union more comparable to the United States, where about 65 percent of total government spending is at the federal level. The ability to raise federal taxes and to issue federal debt would be part of this scenario. Reaching this last step would essentially mean the end for national fiscal policy coordination. There would be a euro-area fiscal capacity of sufficient size to deal with all aspects of the euro area's fiscal affairs, ie allocative, redistributive and for stabilisation purposes. National fiscal policy would correspondingly lose importance. In this scenario, the no-bailout clause for nationally-issued debt would be as credible as it can get through design, and would remain central.

\section{Prerequisites for each step}

Achieving different levels of fiscal integration in a currency union is above all a political question. It involves complex questions of political trust, shifting legitimacy and accountability from the national to the supra-national level, and also dealing with different citizens' preferences. In general terms, the provision of European public goods could be done more effectively at the European level because it could take into account the cross-border externalities. However, a more centralised provision of public goods may not be appropriate if citizens have very different preferences.

The achievement of a fiscal union as described in step A boils down to managing important transition questions but also major political questions in relation to banking policies. The full fiscal union of the last step (C) on the other hand involves a level of political integration

13 Claeys et al (2014) computed how a European unemployment insurance scheme with a borrowing capacity could have helped countries such as Spain during the crisis in orders of magnitude of several percentage points of GDP. 
that is very different from today. The second step involves difficulties that are between those of the other two. The time horizon for the different scenarios is different. A time horizon of 2-5 years might be adequate to complete step A, while step C would serve as an analytical benchmark beyond the time horizon of policymakers.

\subsection{Prerequisites for moving forward with step A}

Step A aims to achieve less-intrusive fiscal governance on narrow budgetary matters while Europeanising financial and in particular banking policy. Managing the transition from a predominantly national-based banking system to a European banking policy system remains the central question. This is an ongoing policy debate since the decision of heads of states and government in July 2012 to "break the vicious circle between banks and sovereigns".

\section{Prerequisite 1: Address the fiscal dimension of a banking union}

After the creation of the Single Supervisory Mechanism and the Single Resolution Mechanism, the debate has now shifted to the third pillar of banking union, the European Deposit Insurance System (EDIS). The policy debates on EDIS and on the backstop to the resolution fund are necessary but controversial because they concern the fiscal dimension of banking union (Pisani-Ferry and Wolff, 2012). The primary role of deposit insurance is to create and maintain trust in the financial system. Depositors' confidence in the safety of their deposits in banks is fundamental to financial stability and banking stability in a monetary system based on fiat money. There are three basic arguments that call for the creation of a pooled European insurance system (Wolff, 2016). The first is about size: insurance works better, the greater number of banks that it covers. If insurance in a small country only covers a few banks, a claim could increase the costs of subsequent insurance permanently, thereby imposing a burden on the country's banking system. Second, centralised supervision while deposit insurance is decentralised is inconsistent. In extremis, national deposit insurance and national taxpayers would have to stand ready to address problems that have arisen because of potentially inadequate European supervision. Third, decoupling banks from sovereigns, the very aim of banking union, requires European deposit insurance as otherwise confidence will depend on the creditworthiness of the sovereign. European deposit insurance will therefore increase financial stability and improve crisis management.

\section{Prerequisite 2: Ensure that banking policy is denationalised}

But EDIS and a fiscal backstop alone would not completely denationalise banking policies. Most importantly, bank exposures to sovereign debt must be reduced. Beyond that, the debate also needs to include other policies that materially influence the health of banks, issues such as insolvency legislation and the influence of governments over the ownership of banks.

How can banks' exposure to domestic sovereign debt be reduced? Reducing banks' exposure to sovereign debt is one condition for creating EDIS, as otherwise the insurance would potentially have to cover sovereign problems. But introducing a simple exposure rule or sovereign risk weights can create substantial problems at the point of introduction. The main risk is that holders of weak debt would sell it, thereby triggering a sovereign debt crisis. One option to deal with this transition problem would be to create a transitional buyer. Creation of a joint-and-several stability fund to manage this problem has been suggested by some, but it has been noted by others that the ECB currently is a large buyer of sovereign debt and the risk of introducing exposure rules for banks is therefore muted ${ }^{14}$. Depending on the way banks' debt holdings are reduced, there might be a need to either introduce preferential treatment

14 Corsetti et al (2016); Mogadham (2016). Andritzky et al (2016) propose the introduction of automatic debt restructuring clauses as debt is rolled over. They argue that this would allow for a smooth process. However, in our view, it is unclear whether it would be possible to actually roll over legacy debt when the new debt comes with clear restructuring clauses. Moreover, automatic debt restructuring clauses can create significant financial stability problems. 
of baskets of debt or to introduce safe European debt, possibly in the form of synthetic ESBies (Brunnermaier et al, 2011).

\section{Prerequisite 3: Address non-performing loans in the banking system}

The ability of banks to withstand transition problems as banking union advances depends on the overall state of their balance sheets. Currently, the acute problem of NPLs in a number of countries implies that the financial system is still vulnerable to unforeseen shocks and to new architectural demands. Certainly in transition, addressing the issue of unproductive debt in a timely and effective way is a significant prerequisite for the completion of banking union.

\section{Prerequisite 4: Ensure the legitimacy and accountability of the fiscal backstop}

Creating such a complete banking union framework also raises issues of political accountability. Is the Eurogroup the right political counterpart to Europe's single supervisor? Does the definition of a proper European fiscal backstop not also require the creation of a political head in charge of that backstop? Who would have the legal and political authority to authorise funds? A possible step could be the creation of a permanent Eurogroup president, who would be appointed by the Eurogroup and the European Parliament in euro-area composition. But as long as the resources primarily come from national tax authorities, there will be significant constitutional and political problems. To fully move the framework to a truly centralised authority, a legal base would need to be established.

\section{Prerequisite 5: Reduce interference from the centre in national fiscal policies}

Finally, Europe's current fiscal framework could also be reformed during this step. As the prerequisites we have mentioned are put in place, the no-bailout clause would become more credible, reducing the need for intrusive fiscal monitoring in normal times. We would envisage a reform that pushes the responsibility for achieving sound and stable public finances largely to the national level. Suitable rules could be defined at European level but implemented through national institutions ${ }^{15}$. Overall, this would allow national fiscal policies to play their fiscal stabilisation role in full, depending only on the available fiscal space and not on political constraints arising out of the application of Stability and Growth Pact recommendations.

\subsection{Prerequisites for moving forward with step B}

Building on what would have been achieved in step A, step B would allocate some fiscal resources to the centre to provide for common public goods, to increase and finance European investment and to insure against large, country-specific shocks. By allocating funds to the centre, this scenario would be a clear departure from the current system and therefore would require new agreements between members. We would envisage that these resources would be used for managing border protection, perhaps even defence, investment and European unemployment re-insurance in the event of major shocks. The key issues for discussion are financing and governance.

\section{Prerequisite 1: Finance public goods that are truly European in nature}

Providing European public goods is, above all, a question of political will. In current circumstances, there is an emphasis on demonstrating to citizens that EU policies provide concrete value added. The sources of financing are important. Most of these public goods are not specific to the euro area. Some are directly related to the Schengen area while others are related to the EU. The EU budget could be the main vehicle for such public goods. Arguably, part of the funding could come from a spending review of the current EU budget. The question is then where the additional fiscal resources should come from. In principle, they could

15 An example of a new rules framework would be along the lines of Claeys, Darvas and Leandro (2016) with emphasis on government expenditure, debt and a special golden rule to allow for investment expenditure. 
either be a contribution from national budgets or a new tax resource at the central level. These options would have very different implications in terms of governance, legal base and also their economic stabilisation properties.

\section{Prerequisite 2: Establish a system of checks and balances}

How can political checks and balances, accountability and good governance be ensured? The more functions are centrally provided in the EU, the more this question is central. For example, external border control is a topic of great importance to citizens. While it can be provided through a technical authority like Frontex, there needs to be a political mandate and clear rules of political accountability for such authority's actions. Equally important is execution, effectiveness, decision processes and involvement of national authorities. The more centralised the execution of tasks becomes, the more the legitimacy and checks and balances need to come from centralised bodies. Political legitimacy cannot come only from intergovernmental mechanisms but would need to also involve community sources.

\section{Prerequisite 3: Improve resilience to shocks}

Improving structures that increase resilience to shocks is indispensable for sharing risks coming from large shocks ${ }^{1616}$. Monetary union lacks the exchange rate as an adjustment channel. Therefore, other adjustment mechanisms, such as flexible labour markets, are needed to cater for shocks ${ }^{1717}$. However, adjustment mechanisms in the form of more flexible labour markets can also interfere with Europe's social model.

Additional fiscal risk-sharing will require institutional convergence so that country policy responses to similar shocks are not free-riding on insurance. For example, creating a system that can re-insure national unemployment insurance would require some minimal convergence on labour market institutions. But full European unemployment insurance would require fairly converged or even a single set of labour market institutions.

The more one wanted to increase fiscal risk sharing, the more important it would be to reduce real economic dispersion and enhance political legitimacy.

\subsection{Prerequisites for moving forward with step C}

Step $C$ requires that all the prerequisites for A and B are in place. This implies that the establishment of European banking union with common supervision and backed by a European deposit guarantee system and a fiscal backstop. Also, domestic banking sectors will have a looser relationship to the sovereign than currently, reducing their mutual dependence. There will be clear identification of what constitutes a European public good and a centralised budget that will provide for it. Clear rules on how responsibilities are divided and accountability is sought will have been established. Sufficient structural convergence will have been achieved to increase resilience to country-specific shocks.

Although short of a full fiscal union, such starting conditions will mean that some fiscal resources have already been pooled. The countries themselves, however, remain in charge of fiscal budgets and are thus responsible for contributing to their own macroeconomic stabilisation. We identify two prerequisites to move forward.

\section{Prerequisite 1: Reduce real economic dispersion}

Experience shows that structural differences can be persistent. And while there has been some convergence in the euro area, the differences in income levels are still larger than in the US (Table 1). Direct fiscal transfers from relatively rich to relatively poor regions exist in full federations to help sustain their cohesiveness. But if differences are too large, they may not be sustainable politically. However, differences in euro-area employment rates are comparable 
to those in the US, potentially allowing for a form of partial unemployment insurance.

Table 1: Real economic dispersion across the euro-area countries by comparison to US states: GDP per capita and employment rate

\begin{tabular}{cccc}
\hline Coeff. of variation & $\begin{array}{c}\text { Euro area (w/o Lux) } \\
1999\end{array}$ & $\begin{array}{c}\text { Euro area (w/o Lux) } \\
2015\end{array}$ & $\begin{array}{c}\text { United States (w/o } \\
\text { DC) } 2015\end{array}$ \\
\hline GDP per cap. & 0.54 & 0.41 & 0.18 \\
\hline Employment rate & 0.07 & 0.06 & 0.07 \\
\hline
\end{tabular}

Source: Bruegel based on AMECO (ECFIN) and Bureau of Economic Analysis. Note: GDP per capita and employment rate in percent of the working age population. The coefficient of variation is a normalised measure of dispersion that allows comparisons. Higher values indicate more significant differences across states. Numbers based on 18-member euro area. For employment rates we have also considered the original 11-euro area members (without Luxembourg) instead: 0.059 and 0.052 for 1999 and 2015 respectively.

Reducing real economic differences could help increase the appetite for risk sharing. Structural reforms that, for example, improve the effectiveness of the justice system and the government sector more broadly, improve educational outcomes, enable better management of the debt overhang and insolvencies, or improve the resilience of the financial system, are important for the growth performance of our economies and for their resilience against global shocks. We consider progress in these areas an important political condition for more far-reaching fiscal risk-sharing but we note that fiscal transfers aim at increasing cohesiveness of unions with different living standards.

\section{Prerequisite 2: Taxation and representation}

Shifting macroeconomic stabilisation from the national level to the European centre requires a major shift in sovereignty, spending and taxation to the European level. It would require the political will to grant direct authority to raise taxes and political authority to form a proper euro-area government in charge of the policy areas that are centralised. For this to happen, it would be fundamental to move to a different level of democratic accountability and institutions. The outcome would be essentially a political union with democratic decision-making at the federal level and executive authority at that level. Achieving such a vision is, to our mind, far away. Perhaps the most important prerequisite would be a clear sense of European identity among citizens.

\section{Conclusions}

Increasing fiscal capacity is desirable for the economic stability of the euro area and would improve economic performance. But advancing this agenda is difficult politically and raises serious questions about cohesiveness and how much economic convergence is needed. We have discussed possible conditions that in our view would make progress easier. The question then is what types of policies are available to policymakers and what European-level involvement is desirable. Instruments such as the Macroeconomic Imbalance Procedure have proven rather ineffective. Ultimately, it is up to national policymakers to act and to European partners to coordinate their actions to make progress and create institutions that allow for legitimate and efficient risk sharing and better management of the euro area's fiscal stance. It is also about generating trust by implementing decisions and delivering results that are visible to all. 


\section{References}

Andritzky J., D. I. Christofzik, L. P. Feld and U. Scheuering (2016) 'A mechanism to regulate sovereign debt restructuring in the euro area, Working paper 04/2016, German Council of Economic Experts

Baldwin, R. and F. Giavazzi (2015) 'The Eurozone crisis: a consensus view of the causes and a few possible solutions', Policy Insight 85, Centre for Economic Policy Research, available at http://voxeu.org/sites/ default/files/file/Policy\%20Insight\%2085.pdf

Bayoumi, T. and B. Eichengreen (1994) 'Shocking Aspects of European Monetary Unification', in F. Giavazzi and F. Torre (eds) Adjustment and Growth in the European Monetary Union, Cambridge University Press.

Benassy-Quéré A., X. Ragot and G. Wolff (2016) 'Which Fiscal Union for the euro area?' Policy Contribution 2016/05, Bruegel, available at http://bruegel.org/2016/02/which-fiscal-union-for-the-euro-area/

Bordo, M., A. Markiewicz and L. Jonung (2011) 'A fiscal union for the euro: Some lessons from history', Working Paper No. 17380, NBER

Brunnermeier M., L. Garicano, P. R. Lane, M. Pagano, R. Reis, T. Santos, S.Van Nieuwerburgh and D. Vayanos (2011) 'ESBies: a realistic reform of Europe's financial architecture', VoxEU, 25 October, available at http://voxeu.org/article/esbies-realistic-reform-europes-financial-architecture

Claeys, G., Z. Darvas and G. Wolff (2014) 'Benefits and drawbacks of European Unemployment Insurance,' Policy Brief 2014/06, Bruegel

Claeys, G. and Z. Darvas (2015) 'The financial stability risks of ultra-loose monetary policy', Policy Contribution 2015/03, Bruegel

Corsetti, G., L. Feld, R. Koijen, L. Reichlin, R. Reis, H. Rey and B. Weder di Mauro (2016) 'Reinforcing the Eurozone and protecting an open society', VoxEU, 27 May, available at http://voxeu.org/article/reinforcing-eurozone-and-protecting-open-society

Darvas, Z. and A. Leandro (2015) 'The limitations of policy coordination in the euro area under the European Semester', Policy Contribution 2015/19, Bruegel.

Demertzis, M. and A. Hughes Hallett (1998) 'Asymmetric Transmission Mechanisms and Divergence in Europe: A story of structural differences vs. policy failures?' Journal of Economic Dynamics and Control 22(6), 869-886.

Demertzis, M., A. Hughes Hallett and O. Rummel (2000a) 'Is the European Union a Natural Currency Area, or is it Held Together by the Policy Makers?' Weltwirtschaftliches Archives, Band 136, Heft 4, 657-679.

Demertzis, M., A. Hughes Hallett and Y. Ma (2000b) 'The Single Currency and Labour Market Flexibility: a Necessary Partnership?' Scottish Journal of Political Economy, May: 141-155.

Eichengreen, B. and J. von Hagen (1996) 'Fiscal policy and Monetary Union: Is There a Trade-off between Federalism and Budgetary Restrictions?' American Economic Review, Vol 86(2): 134-38

Eichengreen, B. and C. Wyplosz (2016) 'Minimal conditions for the survival of the euro', Forum, Intereconomics: 24-28, available at http://archive.intereconomics.eu/downloads/getfile.php?id=970

Frankel, J. and A. Rose (1998), The Endogeneity of the Optimum Currency Area Criteria, Economic Journal 108, July, 1009-1025.

Frieden, J. (2016) Lessons for the euro from early American Monetary and Financial History, Essay and Lecture Series, Bruegel, available at http://bruegel.org/2016/05/lessons-for-the-euro-from-early-usmonetary-and-financial-history/

Gabriel, S. and M. Schulz (2016) 'Europa neu gründen', letter to Spiegel Online, 24 June

Henning, C.R and M. Kessler (2012) Fiscal Federalism: US history for architects of Europe's fiscal Union, Essay and Lecture Series, Bruegel, available at http://bruegel.org/2012/01/fiscal-federalism-us-history-for-architects-of-europes-fiscal-union/

Macron, E. and S. Gabriel (2015) 'Europe, cannot wait any longer: France and Germany must drive ahead', The Guardian, 3 June, available at https://www.theguardian.com/commentisfree/2015/jun/03/ europe-france-germany-eu-eurozone-future-integrate

Marzinotto, B., A. Sapir and G. Wolff (2011) 'What kind of fiscal union?' Policy Brief 2011/06, Bruegel

Mody, A. (2014) 'Kohl's Euro', Bruegel Blog, 23 December

Mody, A. (2015) 'Living (dangerously) without a fiscal union', Working Paper 2015/03, Bruegel, available at http://bruegel.org/wp-content/uploads/imported/publications/WP_2015_03.pdf

Moghadam, R. (2016) 'A modest proposal on quantitative easing to soothe warring sides', Financial Times, 12 June

Pisani-Ferry, J., E. Vihriälä and G. Wolff (2013) ‘Options for a Euro-area fiscal capacity', Policy Contribu- 
tion 2013/01, Bruegel

Pisani-Ferry, J. (2016) ‘The Eurozone's Zeno paradox and how to solve it', Voxeu.org, 10 April

Pissarides, C. (1997), The need for labour market flexibility in a European economic and monetary union, Swedish Economic Policy Review 4, 513-546.

Schäuble, W. (2016) 'In Europa nicht so weitermachen wie bisher', interview in Die Welt, 3 June

Tusk, D. (2016) Speech by President Donald Tusk at event marking the $40^{\text {th }}$ anniversary of EPP, available

at http://www.consilium.europa.eu/en/press/press-releases/2016/05/30-pec-speech-epp/

Van Rompuy, H. (2012) Towards a Genuine Economic and Monetary Union, Council of the European Union, 5 December

Verhofstadt, G. (2016) 'Only more Europe can beat Europe's nationalists', Project Syndicate, available at https://www.project-syndicate.org/commentary/post-brexit-eu-structural-reforms-by-guy-verhofstadt-2016-07

Von Hagen, J. (2014) 'Governance of the Euro Area: Fiscal Union, Debt Union, Fiscal Freedom, Wirtschaftsdienst Zeitschrift fur Wirtschaftspolotik, 94(13): 23-27, available at http://archiv.wirtschaftsdienst.eu/jahr/2014/13/governance-of-the-euro-area-fiscal-union-debt-union-fiscal-freedom/

Wolff, G. (2016) 'The European Deposit Insurance Scheme', Bruegel Blog, 23 May, available at http://bruegel.org/2016/05/the-european-deposit-insurance-scheme/

\section{Annex}

Table: Summary of conditions necessary to achieve greater fiscal centralisation

\begin{tabular}{lll}
\hline & \multicolumn{1}{l}{ Fiscal centralisation element } & \multicolumn{1}{c}{ Conditions } \\
\hline Scenario A & $\begin{array}{l}\text { Deposit insurance \& fiscal } \\
\text { backstop } \\
\text { Less intrusive intervention on } \\
\text { national fiscal policies from } \\
\text { centre }\end{array}$ & $\begin{array}{l}\text { Greater credibility of no-bailout } \\
\text { clause }\end{array}$ \\
& $\begin{array}{l}\text { Address fiscal dimension of bank- } \\
\text { ing union }\end{array}$ \\
& $\begin{array}{l}\text { Denationalise banking policy } \\
\text { framework }\end{array}$ \\
& $\begin{array}{l}\text { Address non-performing loan } \\
\text { problems } \\
\end{array}$ \\
& $\begin{array}{l}\text { Address the issue of legitimacy } \\
\text { and accountability of the fiscal } \\
\end{array}$ \\
& backstop \\
& Reduce interference in national \\
& fiscal policies from the centre
\end{tabular}

reserved. Short sections, not to exceed two paragraphs, may be quoted in the original language without explicit permission provided that the source is acknowledged. Opinions expressed in this publication are those of the author[s] alone.

Bruegel, Rue de la Charité 33, B-1210 Brussels

(+32) 22274210

info@bruegel.org

www.bruegel.org

Scenario B

- Provision of European public goods

- Resources for investment spending

- Re-insurance system to address large country-specific shocks
- Finance public goods that are of true European nature

- Establish a system of checks and balances

- Structural convergence for increased ability to react to shocks 